\title{
'Doce do Havaí' Maize Cultivar Presents Tolerance to Saline Stress in Hydroponic Cultivation
}

\author{
Ana Claudia Viana, Andira Pricila Dantas, Renato Fernando Menegazzo, Sonivaldo Ruzzene \\ Beltrame, Ana Daniela Lopes (Corresponding Author) \\ Paranaense University, Brazil
}

Received: Nov. 17, 2019

Accepted: Dec. 30, 2019

Published: Jan. 3, 2020

doi:10.5296/jas.v8i2.15791

URL: https://doi.org/10.5296/jas.v8i2.15791

\begin{abstract}
This study evaluated the effects of salinity on the development, growth and biomass production of two sweet maize genotypes ('Tropical Plus ${ }^{\circledR}$ ' and 'Doce do Havaí') and compared the oxidative stress marker responses of plant tissues from roots and leaves of different seedlings submitted to different amounts of $\mathrm{NaCl}$ in a nutrient solution. The experiment was carried out in a complete random design, in a $2 \times 4$ factorial arrangement (two sweet maize genotypes and four salt concentrations: 0, 50, 100 and $150 \mathrm{mM} \mathrm{NaCl}$ ). Previously, the seeds were distributed in Styrofoam trays containing commercial substrate and, 10 days after sowing, the seedlings were transferred to 2-litter plastic pots, containing nutrient solution without $\mathrm{NaCl}$ addition, where they were kept for 8 days. $\mathrm{NaCl}$ was added to the nutrient solution, according to the treatments. Each treatment consisted of four pots containing six plants each. The plants were kept in B.O.D. at $25^{\circ} \mathrm{C}$ with $18 / 6$ light for 14 days. The nutrient solution with $\mathrm{NaCl}$ addition was changed every 7 days until the end of the experiment. Saline stress reduced root $\left(13 \%\right.$ and $29 \%$ for Hawaiian and 'Tropical Plus ${ }^{\circledR}$ ', respectively) and shoot length (36\% for 'Doce do Havaí' and 48\% for 'Tropical Plus ${ }^{\circledR}$ '), fresh shoot (29\% for 'Doce do Havaí' genotype, and 70\% for 'Tropical Plus ${ }^{\circledR}$ ') and root mass ( $18 \%$ and $38 \%$ for 'Doce do Havaí' and 'Tropical Plus ${ }^{\circledR}$ ', respectively), shoot diameter ( $18 \%$ and $20 \%$ for 'Doce do Havaí' and 'Tropical Plus ${ }^{\circledR}$ ', respectively) and chlorophyll content in both genotypes, with results more significative in 'Tropical Plus ${ }^{\circledR}$ ' hybrid seedlings. However, the concentrations of proline and malondialdehyde in roots and leaves, as well as conductivity, increased in response to the addition of $\mathrm{NaCl}$, mainly in 'Doce do Havaí'. These results suggest that the 'Doce do Havaí' genotype is more tolerant to salinity compared to 'Tropical Plus ${ }^{\circledR}$ ' hybrid, and may be indicated for breeding programs aiming to develop saline tolerant plants.
\end{abstract}

Keywords: Zea mays L., NaCl, salinity, nutrient solution 


\section{Introduction}

Sweet maize has been developed from a common maize natural mutation caused by mutant recessive genes that are responsible for alterations in the endosperm composition, making it highly nutritious and sweet (Tracy, 2001). Botanically classified as Zea mays L. saccharata Sturt, this product is exclusively utilized "in natura" or processed for human consumption (Oliveira Junior et al., 2006). Its total production is nearly all directed to the canning industry (Abreu de Jesus et al., 2016).

In Brazil, sweet maize is not a very popular crop. Its cultivation occurs in approximately 36 thousand acres and $90 \%$ of it is concentrated in the state of Goiás (Barbieri, 2010). Moreover, its productivity is $28 \%$ lower than the one reached by countries with temperate weather such as the USA and Canada. However, there is a potential to improve these rates since it is a product with great aggregated value and that has been introduced to big consuming markets (Bordallo et al., 2005).

One of the reasons of the lack of sweet maize popularity is farmers' unfamiliarity with the crop, high production cost especially for the acquisition and treatment of seeds, great expenses with manual operations, and lack of available cultivar options in the market (Abreu de Jesus et al., 2016). However, the interest in sweet maize has been growing, making seed companies keep plant breeding programs, and consequently generating commercial hybrids with high productivity and grain yield (Luz et al, 2014).

Despite the advances observed in sweet maize cultivation, more studies are needed to evaluate other essential characteristics for the industry and farmers such as corncob shape, its behavior after industrial processing, seed quality, tolerance to plagues and diseases, and aspects that interest the consumer like color, taste and texture (Luz et al, 2014). Moreover, factors such as saline stress should also be studied because they influence the growth and productivity of crops in general worldwide (Islã and Aragués, 2010).

Soil salinization is a typical process of arid and semiarid regions due to low rainfall, high evaporation rate, and low natural draining capacity, making non-leaching salts accumulate at harmful levels to plant growth (Soares Filho et al., 2016). The exploitation of natural resources utilizing inappropriate techniques contributes to worsen this problem. An increase in salt concentration can cause farming land abandonment in few years; the great amounts of salt in the soil cause alterations in the soil chemical characteristics, retarding or preventing plant growth, due to the increase of its osmotic potential and indirect toxicity by specific elements (Pedrotti et at., 2015).

Maize is classified as moderately sensitive to salinity, with a threshold salinity of $1.1 \mathrm{dS} \mathrm{m}^{-1}$ and $1.7 \mathrm{dS} \mathrm{m}^{-1}$ (Ayers and Westcot, 1999), however, salinity tolerance varies between in species and genotypes, the effect of saline stress is dependent on factors such as developmental stages, environmental factors, cultivar, salt type, intensity and duration of salt stress, crop and irrigation management and edaphoclimatic conditions. Therefor it is recommended that all essential nutrients be applied in appropriate amounts in order to evaluate genotypes regarding their tolerance to salinity. Therefore, the utilization of nutrient 
solutions, applied through hydroponic systems, allows a control of slat balance in the solution as well as the available nutrient contents to plants (Soares Filho et al., 2016). Thus, this study aimed to evaluate saline stress in the growth parameters and oxidative stress markers of leaves and roots of 'Doce do Havaí' and 'Tropical Plus ${ }^{\circledR}$ ' genotypes cultivated in nutrient solutions.

\section{Materials and Methods}

\subsection{Plant Material and Salinization of the Cultivation Medium}

The experiment was carried out in Campus III and the Main Campus of Paranaense University - UNIPAR, in the city of Umuarama, PR. The plant material consisted of two sweet maize (Zea mays L. saccharata Sturt) genotypes: 'Doce do Havaí' and 'Tropical Plus ${ }^{\circledR}$ ', a commercial hybrid. None of the evaluated materials have been reported regarding their tolerance to abiotic stresses. The experiment had a 2 x 4 (genotypes $\mathrm{x} \mathrm{NaCl}$ concentrations) complete random design with 3 replications per treatment: $0,50,100$, and $150 \mathrm{mM}$ of $\mathrm{NaCl}$.

Previously, seeds of two genotypes were distributed in Styrofoam trays containing commercial substrate. Ten days after seeding, the seedlings were transferred to plastic pots $(12 \times 15.50 \times 11 \mathrm{~cm})$, each one containing $2 \mathrm{~L}$ of whole Hoagland nutrient solution (1950). After 7 days, the solution was substituted for half Hoagland solution with or without addition of $\mathrm{NaCl}$ according to the treatments, and the seedlings were kept under these conditions for 14 days. Each one of the pots had six seedlings of each genotype, totaling 24 plants per treatment.

Each pot consisted of an experimental unit that was kept in a B.O.D. incubator, regulated at a temperature of $25^{\circ} \mathrm{C}$, a photoperiod of $18 / 6 \mathrm{~h}$ light, daily ventilation for $30 \mathrm{~min}$ and luminosity of $126.97 \mu \mathrm{mol} \mathrm{m} \mathrm{m}^{-2}$.

\subsection{Growth Parameters}

The following parameters were evaluated 31 days after sowing in three plants per treatments: shoot $(\mathrm{cm})$ and root $(\mathrm{cm})$ lengths, fresh shoot mass $(\mathrm{g})$, fresh root mass $(\mathrm{g})$ and shoot diameter $(\mathrm{cm})$, indirect measurement of chlorophyll rates, malondialdehyde concentration (nmol MDA $\left.\cdot \mathrm{g}^{-1} \mathrm{FM}\right)$, and proline concentration ( $\mu \mathrm{g}$ proline $\left.\cdot \mathrm{g}^{-1} \mathrm{FM}\right)$.

The plant height and root length were measured with a $150-\mathrm{mm}$ universal digital pachymeter. The shoot base until the last visible leaf was measured to estimate the shoot length. The fresh shoot mass was weighed in a semi-analytical scale. The shoot diameter was also determined with a digital pachymeter, measuring the medial part of the stem.

\subsection{Chlorophyll Index}

The chlorophyll index was determined in the area units through a portable chlorophyll meter SPAD-502 (Soil and Plant Analysis Development - Minolta Co), through two readings in each of the evaluated plants. The index $\left(\mu \mathrm{g} \cdot \mathrm{cm}^{-2}\right)$ was obtained from the average of both values according to the recommendations by Amarante et al. (2010). 


\subsection{Oxidative Stress Markers}

\subsubsection{Malondialdehyde}

The lipid peroxidation level was determined according to Cakmak and Hosrt (1991) by estimating malondialdehyde (MDA) content. The lipid peroxidation was estimated as the total content of reactive (Thiobarbituric Acid) TBA substances and expressed as MDA equivalents. The MDA molar extinction coefficient $\left(155 \mathrm{mmol} \cdot \mathrm{cm}^{-1}\right)$ was utilized for calculations.

\subsubsection{Membrane Damage}

The membrane damage percentage $(\% \mathrm{MD})$, estimated from electrolyte leakage, was determined from five 3-cm diameter leaf disks immersed in distilled water. The disks were kept in assay tubes under agitation during $24 \mathrm{~h}$ at $28{ }^{\circ} \mathrm{C}$. Next, the electric conductivity reading of the solution $\left(\mathrm{L}_{1}\right)$ was done. Afterwards, the tubes were incubated in water bath for $1 \mathrm{~h}$ at $100{ }^{\circ} \mathrm{C}$, and after cooling at ambient temperature, another electric conductivity reading of the solution $\left(\mathrm{L}_{2}\right)$ was done. The \% MD was estimated by the equation $\mathrm{MD}=$ $\left(\mathrm{L}_{1} / \mathrm{L}_{2}\right)^{*} 100$ (Blum and Ebercon, 1981; Silveira et al., 2001).

\subsubsection{Proline Content}

The proline concentration was determined according to the methodology by Bates et al. (1973). The proline concentration was determined using a standard L-proline curve (Synth).

\subsection{Data Analysis}

After treatment, the data were submitted to analysis of normality using Shapiro-Wilk's test. After confirming parametricity, they were evaluated by ANOVA at 5\% of significance. When significant by $\mathrm{F}$ test, they were submitted to regression analysis for the concentration deployment in each genotype, and to Tukey's for the genotypes in each concentration at 5\% probability. The analyses were done using the statistical program Sisvar 5.6 (Ferreira, 2011).

\section{Results}

\subsection{Growth Parameters and Biomass Production}

Salinity reduced shoot length (SL). At the concentration of $150 \mathrm{mM}$, there was a reduction of $36 \%$ and $48 \%$ in 'Doce do Havaí' and 'Tropical Plus ${ }^{\circledR}$ ' seedlings, respectively. The effect of salt addition on SL was significant to 'Doce do Havaí' as well as 'Tropical Plus ${ }^{\circledR}$ ', with an average difference of 18 and $35 \%(p \leq 0.05)$, respectively at the concentrations of 50 and 100 $\mathrm{mM}$ (Table 1). The relation between the salt concentration in the cultivation medium and SL in both varieties was shown by a decreasing linear equation (Table 1). Thus, it was evident that the addition of $\mathrm{NaCl}$ in the cultivation medium reduced the height of 'Doce do Havaí' and, mainly, of 'Tropical Plus ${ }^{\circledR}$ '. 
Table 1. Shoot length and Root length (cm), Fresh shoot mass and Freshh root mass (g) and Shoot diameter $(\mathrm{cm})$ of Zea mays L. saccharata genotypes, 'Doce do Havaí' and 'Tropical Plus ${ }^{\circledR}$ ', cultivated in nutrient solution at different $\mathrm{NaCl}$ concentrations

\begin{tabular}{|c|c|c|c|c|c|c|}
\hline \multirow[b]{2}{*}{ Treatments } & \multicolumn{6}{|c|}{$\mathrm{NaCl}$ concentration $(\mathrm{mM})$} \\
\hline & [0] & {$[50]$} & {$[100]$} & {$[150]$} & Regression Equation & $\begin{array}{l}\mathrm{R}^{2} \\
(\%)\end{array}$ \\
\hline & \multicolumn{6}{|c|}{ Shoot length - SL $(\mathrm{cm})$} \\
\hline $\begin{array}{l}\text { 'Doce do } \\
\text { Havaí' }\end{array}$ & $52.5 * \mathrm{a}$ & $50.16 \mathrm{a}$ & $41.00 \mathrm{a}$ & $33.50 \mathrm{a}$ & $y=-0.132333 x+54.2167$ & 95.51 \\
\hline $\begin{array}{l}\text { 'Tropical } \\
\text { Plus }{ }^{\circledR} \text { ' }\end{array}$ & $45.66 \mathrm{a}$ & $37.33 b$ & $24.33 b$ & $23.66 \mathrm{a}$ & $y=-0.1580 x+44.600$ & 91.46 \\
\hline \multirow[t]{2}{*}{$\mathrm{CV}(\%)$} & 16.02 & $\begin{array}{l}\text { General } \\
\text { average }\end{array}$ & 38.52 & \pm & & \\
\hline & \multicolumn{6}{|c|}{ Root length - RL (cm) } \\
\hline $\begin{array}{l}\text { 'Doce do } \\
\text { Havaí' }\end{array}$ & $26.46 \mathrm{a}$ & $30.46 \mathrm{a}$ & $24.00 \mathrm{a}$ & $23.00 \mathrm{a}$ & $y=-0.0005 x^{2}+0.41267 x+27.263$ & 61.73 \\
\hline $\begin{array}{l}\text { 'Tropical } \\
\text { Plus }(\AA)\end{array}$ & $22.33 \mathrm{a}$ & $26.16 \mathrm{a}$ & $16.33 \mathrm{a}$ & $15.83 \mathrm{a}$ & $y=-0.00043 x^{2}+0.0063 x+23.483$ & 64.34 \\
\hline \multirow[t]{2}{*}{$\mathrm{CV}(\%)$} & 20.53 & $\begin{array}{l}\text { General } \\
\text { average }\end{array}$ & 23.08 & \pm & & \\
\hline & \multicolumn{6}{|c|}{ Fresh shoot mass - FSM (g) } \\
\hline $\begin{array}{l}\text { 'Doce do } \\
\text { Havaí' }\end{array}$ & $4.00 \mathrm{a}$ & $4.09 \mathrm{a}$ & $2.83 \mathrm{a}$ & $3.32 \mathrm{a}$ & $y=-0.006593 x+4.05533$ & 51.26 \\
\hline $\begin{array}{l}\text { 'Tropical } \\
\text { Plus }(\AA)\end{array}$ & $3.44 \mathrm{a}$ & $2.69 \mathrm{a}$ & $1.19 \mathrm{a}$ & $1.04 \mathrm{~b}$ & $y=-0.017395 x+3.398167$ & 92.49 \\
\hline \multirow[t]{2}{*}{$\mathrm{CV}(\%)$} & 37.37 & $\begin{array}{l}\text { General } \\
\text { average }\end{array}$ & 2.83 & $\begin{array}{l} \pm \\
1.417 \\
\end{array}$ & & \\
\hline & \multicolumn{6}{|c|}{ Fresh root mass - FRM (g) } \\
\hline $\begin{array}{l}\text { 'Doce do } \\
\text { Havaí' }\end{array}$ & $1.95 \mathrm{a}$ & $1.7 \mathrm{a}$ & $1.59 \mathrm{a}$ & $3.40 \mathrm{a}$ & $\begin{array}{l}\mathrm{y}=0.000205 \mathrm{x}^{2}-0.022307 \mathrm{x}+ \\
2.0347\end{array}$ & 92.66 \\
\hline $\begin{array}{l}\text { 'Tropical } \\
\text { Plus }(\AA)\end{array}$ & $1.23 \mathrm{a}$ & $0.73 b$ & $0.76 b$ & $0.81 b$ & $y=0.000055 x^{2}-0.0108+1.20795$ & 92.33 \\
\hline \multirow[t]{2}{*}{$\mathrm{CV}(\%)$} & 31.66 & $\begin{array}{l}\text { General } \\
\text { average }\end{array}$ & 1.52 & \pm 0.94 & & \\
\hline & \multicolumn{6}{|c|}{ Shoot diameter - SD $(\mathrm{cm})$} \\
\hline $\begin{array}{l}\text { 'Doce do } \\
\text { Havaí' }\end{array}$ & $4.54 \mathrm{a}$ & $4.09 \mathrm{a}$ & $3.67 \mathrm{a}$ & $6.09 \mathrm{a}$ & $\begin{array}{l}\mathrm{y}=0.000285 \mathrm{x}^{2}-0.034237 \mathrm{x}+ \\
4.67483\end{array}$ & 88.49 \\
\hline $\begin{array}{l}\text { 'Tropical } \\
\text { Plus } \AA \text { ' }\end{array}$ & $3.63 \mathrm{a}$ & $3.39 \mathrm{a}$ & $2.90 \mathrm{a}$ & $3.34 b$ & $y=0.000068 x^{2}-0.01288 x+3.686$ & 74.47 \\
\hline $\mathrm{CV}(\%)$ & 20.16 & $\begin{array}{l}\text { General } \\
\text { average }\end{array}$ & 3.96 & \pm & & \\
\hline
\end{tabular}

*Averages followed by the same letters in the column did not differ statistically among themselves by Tukey's test at 5\% of probability. CV: Coefficient of Variation.

Salinity also reduced root length (RL). The decrease in seedlings cultivated at $150 \mathrm{mM}$ of $\mathrm{NaCl}$ was $13 \%$ for 'Doce do Havaí', and $29 \%$ for 'Tropical Plus ${ }^{\circledR}$ '. In the genotype comparison (Table 1), the effect of the saline stress on the averages was not significant ( $>0.05$ ). The regression model for both genotypes was quadratic (Table 1). Therefore, the quadratic equation confirmed the analysis of variance and showed that a greater effect of saline stress on RL occurred for ‘Tropical Plus ${ }^{\circledR}$ ' hybrid. 


\section{Macrothink}

The saline stress reduced fresh shoot mass (FSM) of seedlings up to $29 \%$ for 'Doce do Havaí' genotype, and $70 \%$ for 'Tropical Plus ${ }^{\circledR}$ '. Between the genotypes, the effect of $\mathrm{NaCl}$ addition on FSM was significant $(\mathrm{p} \leq 0.05)$ at the concentration of $150 \mathrm{mM}$ of $\mathrm{NaCl}$ (Table 1). The relation between the salt concentration in the cultivation medium and FSM inof both varieties was demonstrated by a decreasing linear equation (Table 1), making evident that the addition of $\mathrm{NaCl}$ in the cultivation medium reduced the fresh shoot mass of 'Doce do Havaí' and, mainly, of 'Tropical Plus ${ }^{\circledR}$ '.

Regarding fresh root mass (FRM) and shoot diameter (SD), the responses to saline stress in general were similar and statistically significant $(\mathrm{p} \leq 0.05)$ for both parameters. However, they were different for each genotype. In 'Doce do Havaí' seedlings cultivated at the concentration of $100 \mathrm{mM}$ of $\mathrm{NaCl}$, there was a reduction of $18 \%$ in FRM in well as SD. In 'Tropical Plus ${ }^{\circledR}$ ' seedlings, the decrease was $38 \%$ in FRM and $20 \%$ in SD. SD presented statistically significant difference $(\mathrm{p} \leq 0.05)$ between the seedlings genotypes cultivated at $150 \mathrm{mM}$ of $\mathrm{NaCl}$. FRM significantly differed $(\mathrm{p} \leq 0.05)$ from one genotype to another in all treatments, except for the control (Table 1).

\subsection{Determination of Chlorophyll Index}

The chlorophyll content was reduced up to $26 \%$ in Hawaiian seedlings and up to $18 \%$ in Tropical Plus when cultivated at $150 \mathrm{mM}$ of $\mathrm{NaCl}$, but the effect of $\mathrm{NaCl}$ addition on the chlorophyll content was not significant $(p>0.05)$ for both genotypes (Table 2). There was statistical difference $(\mathrm{p} \leq 0.05)$ of the salinity content effect on the chlorophyll index alone at all concentrations. The quadratic regression model better adjusted to the salt effects on chlorophyll concentration for both genotypes (Figure 1A). Thus, it was evident that $\mathrm{NaCl}$ addition to the cultivation medium reduced chlorophyll content in both genotypes, mainly in 'Tropical Plus®'. 


\section{1) Macrothink}

Journal of Agricultural Studies

ISSN 2166-0379

2020, Vol. 8, No. 2

Table 2. Chlorophyll content, malondialdehyde concentration in roots and leaves, proline concentration and conductivity of $Z$. mays saccharata seedlings cv. 'Doce do Havaí' and $Z$. mays saccharata $\mathrm{cv}$. 'Tropical Plus ${ }^{\circledR}$ ', cultivated at different $\mathrm{NaCl}$ concentrations

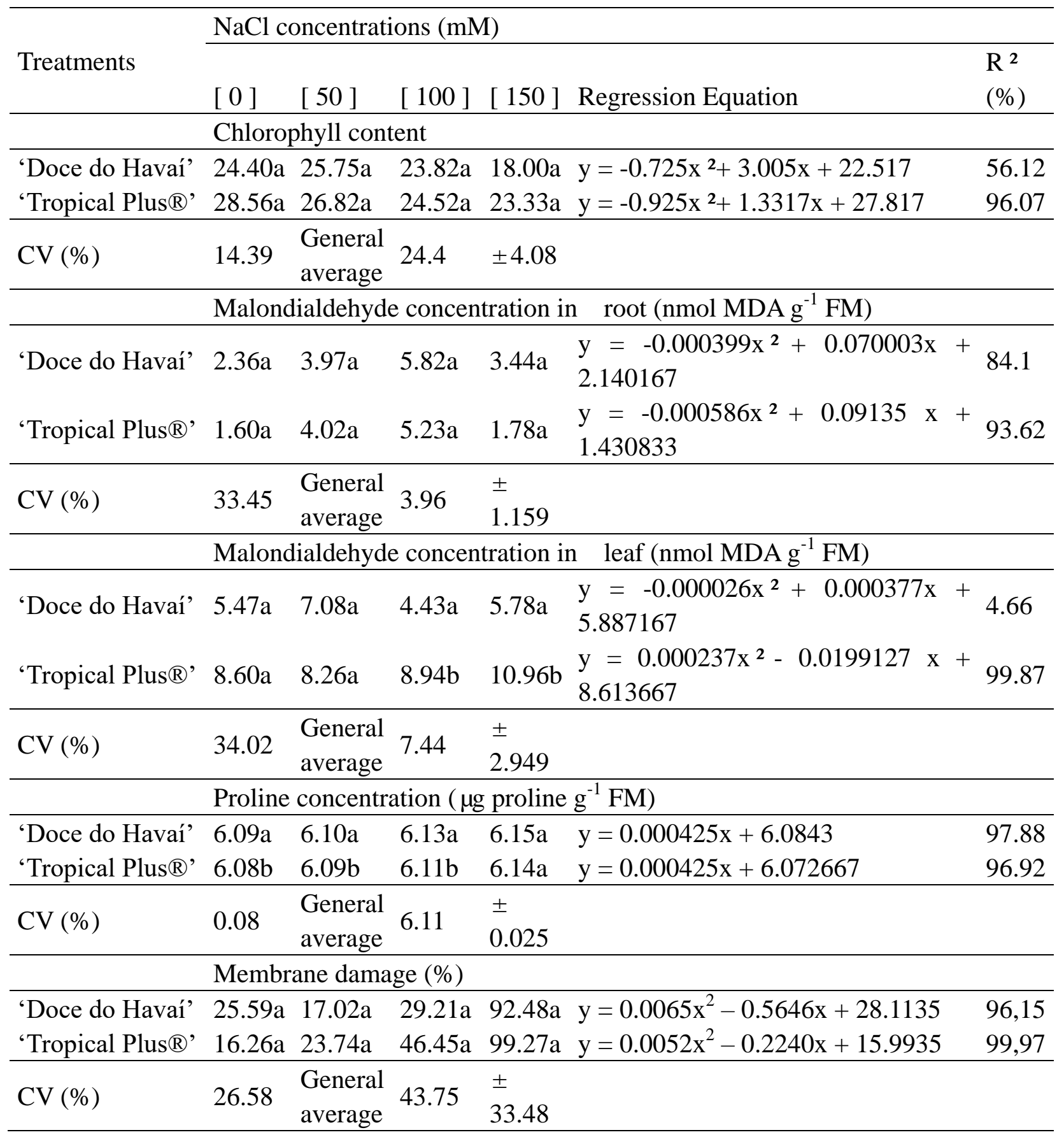

* Averages followed by the same letters in the column do not differ statistically by Tukey's test at 5\% level of significance. CV: coefficient of variation. Source: Research data. 

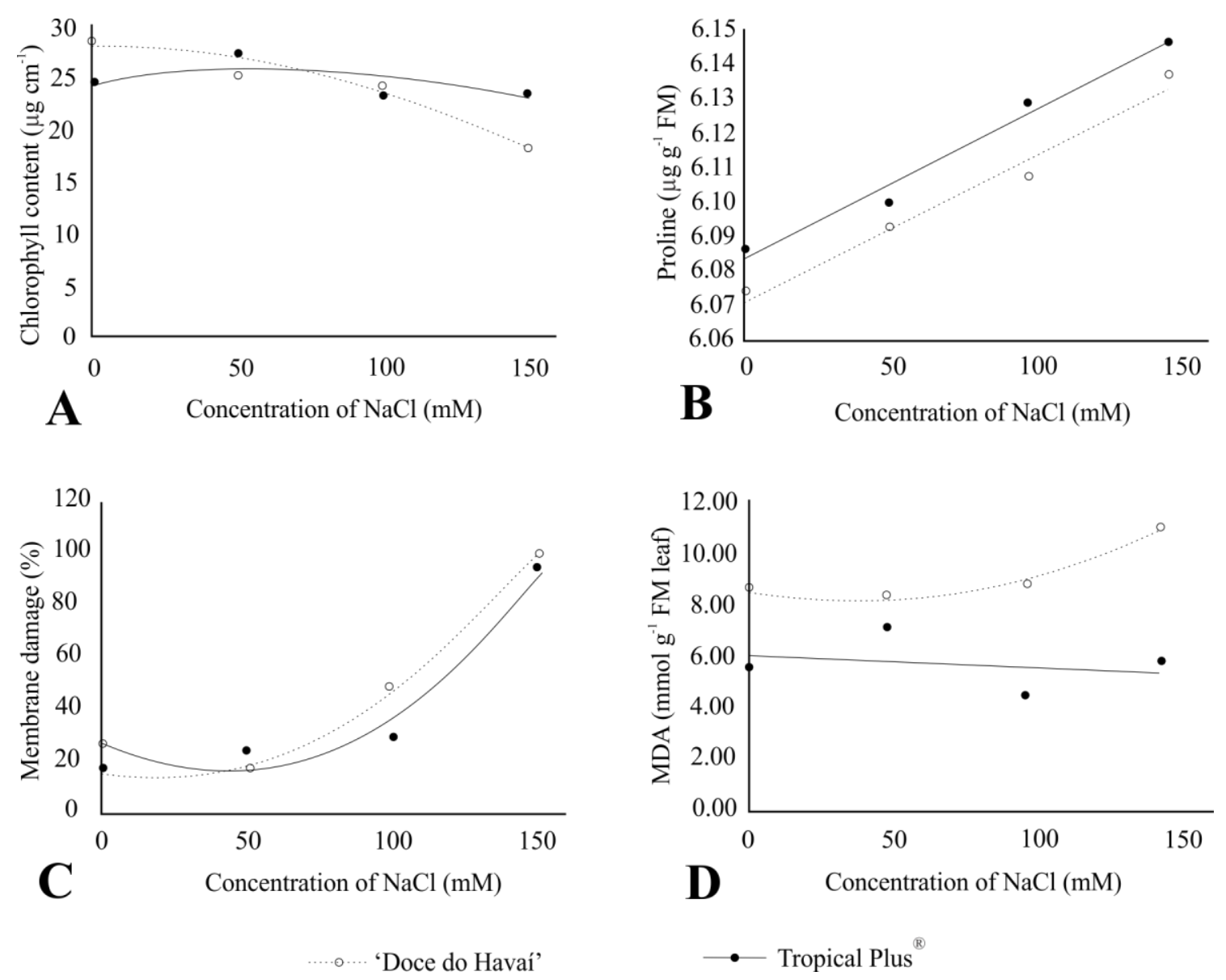

Figure 1. Regression analysis for chlorophyll content (A), proline concentration (B), membrane damage $(C)$ and malondialdehyde concentration in leaves (D) in $Z$. mayssaccharata seedling cv. 'Doce do Havaí' and Z. mays saccharata cv. 'Tropical Plus ${ }^{\circledR}$, cultivated under different $\mathrm{NaCl}$ concentrations

\subsection{Oxidative Stress}

\subsubsection{Malondialdehyde (MDA) Concentration}

Salinity caused an increase in malondialdehyde (MDA) concentration in roots and leaves of 'Doce do Havaí' seedlings as well as of 'Tropical Plus ${ }^{\circledR}$ ' ones. The effect was greater in the leaves of the former when compared to the latter and, the opposite occurred for the roots. However, statistically, the effect of salt addition on MDA/root parameter did not present any significant difference ( $>0.05$ ) in both genotypes (Table 2 ), that is, they responded in the same way to salinization. Regarding the treatment effect on the cultivars, the treatment with $100 \mathrm{mM}$ of $\mathrm{NaCl}$ triplicated MDA amount in 'Tropical Plus ${ }^{\circledR}$ ' seedlings and increased 1.5 fold in 'Doce do Havaí'. The regression model was quadratic for both genotypes (Table 2). Therefore, $\mathrm{NaCl}$ addition to the cultivation medium increased malondialdehyde content in roots of both genotypes, mainly in 'Tropical Plus ${ }^{\circledR}$ ' at the concentration of $100 \mathrm{mM}$.

Salinity increased MDA leaf content in $29 \%$ for 'Doce do Havaí' genotype at the concentration of $50 \mathrm{mM}$ of $\mathrm{NaCl}$, and in $27 \%$ for 'Tropical Plus ${ }^{\circledR}$ ' seedlings at the 
concentration of $150 \mathrm{mM}$. Regarding the salt addition effect on MDA amount in leaves, the result was significant $(\mathrm{p} \leq 0.05)$ for the concentrations of 100 and $150 \mathrm{mM}$ of $\mathrm{NaCl}$ (Table 2). The regression model was quadratic for both genotypes (Figure 1D). Comparing both genotypes, both responded to salinity similarly, that is, without significant difference $(\mathrm{p} \leq 0.05)$. However, the negative values of the quadratic regression coefficient for 'Doce do Havaí indicate that this plant is more tolerant to the effects of saline stress on the lipid peroxidation of leaf tissues compared with 'Tropical Plus ${ }^{\circledR}$ ' hybrid.

\subsubsection{Proline Concentration}

The increase in salt concentration resulted in significant proline content increment $(p \leq 0.05)$ in the seedlings of 'Doce do Havaí' variety as well as for 'Tropical Plus ${ }^{\circledR}$ ' hybrid. However, the analysis of variance of the averages showed that there was a statistical difference $(p \leq 0.05)$ between the genotypes, except at the concentration of $150 \mathrm{mM}$ of $\mathrm{NaCl}$ (Table 2). The relation between salt concentration in the cultivation medium and proline concentration in both varieties was demonstrated by a linear equation whose positive coefficient equals to 0.00042 for 'Doce do Havaí' as well as for 'Tropical Plus ${ }^{\circledR}$ ' (Figure 1B). Therefore, salinity increased proline concentration in both cultivars.

\subsubsection{Membrane Damage}

$\mathrm{NaCl}$ addition increased conductivity of both sweet maize genotypes seedlings without statistical difference between them $(\mathrm{p} \leq 0.05)$ for all concentrations (Table 2). However, at the concentration of $150 \mathrm{mM}$ of $\mathrm{NaCl}$, salinity increased conductivity 3.15 fold in 'Doce do Havaí' and 4.18 fold in 'Tropical Plus ${ }^{\circledR}$ ', when compared to the concentration of $100 \mathrm{mM}$. The regression model for both genotypes was quadratic (Figure 1C). Therefore, it was verified that for both genotypes and for the highest salt concentration $(150 \mathrm{mM})$, the membrane damage leakage had exponential increase compared to lower concentrations.

\section{Discussion}

Munns and Tester (2008) stated that salinity reduces plant growth and productivity. This occurs because the presence of salt affects water availability and reduces water potential in a plant, causing turgor loss and stoma closing. Plants exposed to saline stress decrease their energy expenditure destined to osmoregulation as an adaptive response to the salt presence, aiming to save energy to keep their vital processes (Mansour et al., 2005). These physiological alterations reduce the development and productivity of plants as verified in this study.

The shoot length reduction of $36 \%$ for 'Doce do Havaí' and $48 \%$ for 'Tropical Plus ${ }^{\circledR}$ ' is similar to the results obtained by Shtereva et al. (2015), who observed a reduction of $32 \%$ and $31 \%$ in the height of pure strains of Line 6-13 and Line C-6 sweet maize cultivated with addition of $150 \mathrm{mM}$ of $\mathrm{NaCl}$ for 14 days.

The height reduction of plants exposed to saline stress can be explained by the decrease of growth-promoting hormone synthesis (such as auxins and gibberellins) and by the increase in the production of growth-inhibiting substances (Costa et al., 2007; Rady and Hemida, 2016). 
This occurs because salt alters rates and metabolic pathways of plants, affecting their development (Rahimi et al., 2012; Farooq et al., 2015). Regarding that, Taiz and Zeiger (2009) stated that height is one of the most affected parameters by salinity because the osmotic pressure of the medium decreases water availability to the plant, harming cell division and elongation and, therefore, limiting plant growth.

The shoot length reduction of $29 \%$ for 'Doce do Havai', observed in this study, is in accordance to the results by Shtereva et al. (2015) who verified a decrease of 25 and $24 \%$ in FSM of Line 6-13 sweet maize pure strain and Zaharina hybrid, cultivated in nutrient solution with addition of $150 \mathrm{mM}$ of $\mathrm{NaCl}$ for 14 days. However, the decrease of $70 \%$ in FSM of 'Tropical Plus ${ }^{\circledR}$ ' makes evident that this hybrid is more sensitive to salinity. Nevertheless, similar results under similar cultivation conditions were not found in the literature.

Regarding the effect of salinity on roots, it was observed that the reduction of $13 \%$ and $29 \%$ for root length of Hawaiian and 'Tropical Plus ${ }^{\circledR}$ ', respectively. This is similar to the results obtained by Shtereva et al. (2015), who verified a decrease of 27\%, 23\% and 19\%, respectively, in Line 6-13, Line C-6 and Zaharina RL, cultivated with the addition of 150 $\mathrm{mM}$ of $\mathrm{NaCl}$ for 14 days. In that same experiment, a reduction of $39 \%$ and $43 \%$ occurred in Line C-6 and Zaharina FRM, respectively. This result is similar to the reduction of $38 \%$ in 'Tropical Plus ${ }^{\circledR}$ ' FRM, verified in this study. The reduction of only $18 \%$ for 'Doce do Havaí' FSM was smaller when compared to the studies on saline stress in sweet maize (like it had occurred in RL), suggesting that this genotype is tolerant to saline stress considering that the decrease was smaller than the values verified by Shtereva et al. (2015) in Zaharina, a commercial sweet maize hybrid considered tolerant to salt.

The smallest percentage reduction of RL and FRM when compared to SL and FSM, verified in our study (Table 1), corroborated the results by Munns and Tester (2008), Silva et al., (2011) and Richter et al., (2015), who observed greater reduction shoot growth and productivity rates of plants exposed to saline stress when compared to roots. This explains the fact that roots react more quickly to salinity effects (Azevedo-Neto and Tabosa, 2000; Hsiao e Xu, 2000), balancing water relations in cells and gradually increasing growth rate that, after the osmotic adjustment, becomes stable at lower levels due to stress (Munns, 2002).

Regarding the shoot diameter reduction of $18 \%$ and $20 \%$ for 'Doce do Havaí' and 'Tropical Plus ${ }^{\circledR}$ ' seedlings, respectively (Table 1), Souza et al. (2014) verified a decrease of $6.4 \%$ in plant shoot diameter. This was observed when those authors studied the saline effects on Super sweet Aruba (Feltrim $\left.{ }^{\circledR}\right)$ sweet maize cultivated in soil irrigated with water with low and high salinity ( 0.5 and $4.5 \mathrm{dS} \mathrm{m}^{-1}$ of $\left.\mathrm{NaCl}\right)$. Morales et al. (2001) state that salinity affects each plant part differently, and that the adaptation to the saline medium is different for each species or even to the same variety when at different phenological stages.

There are studies that demonstrate the growth and productivity reduction of plants exposed to saline stress (Mansour et al., 2005). However, as it can be observed in this study, when submitted to this type of stress, different genotypes respond distinctly because the response is 
a plant reaction to an adverse situation and varies according to the genetic factors that regulate the cellular metabolism (Shtereva et al., 2015).

Decreases in nutrient accumulation in several plant parts have been justified by the effect of $\mathrm{NaCl}$ excess on the medium that competes for absorption sites in roots like it occurs with phosphorus, potassium, calcium and magnesium in maize (Sousa et al., 2010). These reductions, however, are not homogeneous, not even in plants of the same species. Plants that synthesize and moderately accumulate a variety of solutes with osmoprotective action of macromolecules show a marginal increase in stress tolerance (Willadino and Camara, 2010).

Proline can attenuate saline stress in young plants. Studies by Hajlaoui et al. (2010) showed that free proline content was significantly increased in plants submitted to stress when compared to control plants of Arper and Aristo maize in all treatments. Free proline concentration showed significant differences between both genotypes in young, mature and senescent leaves. At the concentration of $102 \mathrm{mmol} \cdot \mathrm{L}^{-1}$ of $\mathrm{NaCl}$, the average leaf proline content for young, mature and senescent leaves in Arper was 38, 25 and $14 \mu \mathrm{mol} \cdot \mathrm{g}^{-1} \mathrm{FM}$, respectively. In Artiso, a slight reduction of leaf proline was observed with values of 32, 22, and $13 \mu \mathrm{mol} \cdot \mathrm{g}^{-1} \mathrm{FM}$. At the concentration of $100 \mathrm{mmol} \cdot \mathrm{L}^{-1}$, very close to $102 \mathrm{mmol} \cdot \mathrm{L}^{-1}$ mentioned before, proline content in 'Doce do Havaí' and 'Tropical Plus ${ }^{\circledR}$ ' seedlings were, respectively, 6.13 and $6.11 \mu \mathrm{mol} \cdot \mathrm{g}^{-1} \mathrm{FM}$.

In studies by Hajlaoui et al. (2010) as well as in our study with 'Doce do Havaí' and 'Tropical Plus ${ }^{\circledR}$ ', there was an increase in proline content according to the increase in the evaluated saline concentration. However, studies by Silva et al. (2009), utilizing species with different capacities to accumulate proline in tissues under stress, showed that the tested concentrations were not sufficiently high to cause a significant contribution to the cellular osmotic potential or even to the cellular protection.

Because of divergent results, which seemed contradictory, a better explanation is still needed for the fact that proline contributes to the resistance to saline stress or for the fact that its accumulation is merely related to a metabolic disorder symptom (Silveira et al., 2010).

A plant photosynthetic system is strongly influenced by the availability of factors such as mineral nutrients which can be observed when submitted to stress that affects its osmoregulation (Kaya et al., 2013) such as saline stress. Its deleterious effect results from the increase of chlorophilase enzyme that degrades chlorophyll molecules. The consequence of this is that plants that grow under salinity conditions have their photosynthetic activity damaged/compromised and as a result there is a growth reduction of a smaller leaf area and lower content of this pigment (Mendonça et al., 2010), as observed in 'Tropical Plus ${ }^{\circledR}$ ' when compared to 'Doce do Havaí'.

Results that corroborate the ones observed in this study were found by Lima et al. (2004) when studying rice cultivars submitted to saline stress. When evaluating three genotypes, two were possibly not affected by salinity. On the other hand, the third cultivar presented a decrease in chlorophyll content compared to the control, showing that salinity affected significantly $(\mathrm{p} \leq 0.05)$ the formation of this pigment at concentrations over $25 \mathrm{mM}$ of $\mathrm{NaCl}$, 
as it occurred with 'Tropical Plus ${ }^{\circledR}$ ' genotype, indicating that it is more sensitive to saline stress than 'Doce do Havaí'.

Lipid peroxidation of root and leaf tissue membrane, caused by free radicals, produces Malondialdehyde (MDA). These radicals are formed in stress situations such as the saline one, and affect many biological functions due to structural damages that they cause in the nucleic acid (Bhattacharjee, 2005) and proteins (Zhu et al., 2010). Results that make these effects evident were found by Hajlaoui et al. (2010) in an experimental study aiming to compare the phenolic content of both maize varieties submitted to different $\mathrm{NaCl}$ concentrations and determine more trustworthy leaf indicators to distinguish varieties that are sensitive and tolerant to salt.

Hajlaoui et al. (2010) showed that lipid peroxidation was influenced by saline stress and, increased leaf MDA content as observed in 'Doce do Havaí' and Troplical Plus ${ }^{\circledR}$. The authors verified that the amount of MDA significantly and progressively increased with saline stress and that the highest values were recorded in seedlings treated with $102 \mathrm{mmol} . \mathrm{L}^{-1}$ of $\mathrm{NaCl}$,

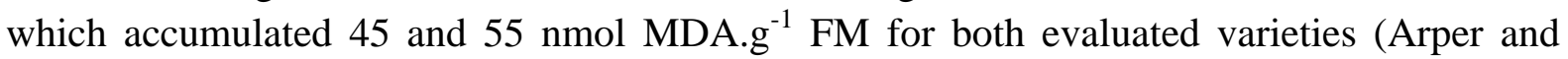
Aristo), respectively.

The capacity to tolerate saline stress was evident in the study by Santos et al. (2016), with AL Bandeirantes maize cultivar. In that study, the water content did not differ statistically, showing that there was not a variation due to the accumulation of soluble compounds responsible for osmotic adjustment. This response possibly indicates an adaptive mechanism in which the stability of water content under saline stress reflects the soluble compound accumulation in leaves, allowing osmoregulation and hydration maintenance as verified by Ragagnin et al. (2014).

Osmoregulation and hydration maintenance are possible because a plant can have several tolerance mechanism (high metabolic activity) and leakage (reduced metabolic activity) to stresses, or a combination of both when compared to another. The individual adjustment in response to these environmental factors consists of resistance mechanisms known as acclimatization (Bray et al., 2000) which is a combination of behavioral, morphological, anatomical, physiological and biochemical processes dependent of molecular processes (Gaspar et al., 2002). Therefore, new studies should be carried out with 'Doce do Havaí' cultivar to confirm its tolerance to $\mathrm{NaCl}$ stress.

\section{Conclusion}

Salinity reduced growth and development of sweet maize plants with different responses for 'Doce do Havaí' and 'Tropical Plus ${ }^{\circledR}$ ' genotypes. The salt addition to the cultivation medium reduced the growth and biomass production as well as the chlorophyll content of seedlings, with smaller effects on 'Doce do Havaí'; it also increased the conductivity and concentrations of malondialdehyde and proline with greater effects on 'Tropical Plus ${ }^{\circledR}$ ' hybrid. These results pointed out that 'Doce do Havai' is more tolerant to saline stress. However, it is recommended that further studies be carried out to investigate the responses of different sweet maize genotypes in salinized soil and/or irrigated with saline water. 


\section{References}

Abreu de Jesus, A., Lima, S. F., Vendruscolo, E. P., Alvarez, R. C. F., \& Contardi, L. M. (2016). Análise econômica da produção do milho doce cultivado com aplicação de bioestimulante via semente. Revista de la Facultad de Agronomía, 115(2), 119-127. http://dialnet.unirioja.es.

Amarante, C. V. T., Steffens, C. A., Sangoi, L., Zanardi, O. Z., Miqueloto, A., \& Schweitzer, C. (2010). Quantificação de clorofilas em folhas de milho através de métodos ópticos não destrutivos. Revista Brasileira de Milho e Sorgo, 9(1), 39-50.

https://doi.org/10.18512/1980-6477/rbms.v9n1p39-50

Ayers, R. S., \& Westcot, D. W. (1999) A qualidade da água na agricultura. 2. ed. Campina Grande: UFPB, 153 p.

Azevedo-Neto, A. D., \& Tabosa, J. N. (2000). Estresse salino em plântulas de milho: parte I análise do crescimento. Revista Brasileira de Engenharia Agrícola e Ambiental, 4(2), 159-164. https://doi.org/10.1590/S1415-43662000000200006

Barbieri, V. H. B. (2010). Mapeamento de QTL em testecrosses de milho doce com diferentes testadores e ambientes. Piracicaba-SP, Brasil: Tese (Doutorado em Ciências) - Universidade de São Paulo (USP) / Escola Superior de Agricultura Luiz de Queiroz.129p. https://doi.org/10.11606/T.11.2010.tde-23062010-091142

Bates, L. S., Waldren, R. P., \& Teares, I. D. (1973). Rapid determination of free proline for water stress studies. Plant and soil, 39(1), 205-207. https://doi.org/10.1007/BF00018060

Bhattacharjee, S. (2005). Reactive oxygen species and oxidative burst: Roles in stress, senescence and signal transduction in plants. Current Science, 89(7), 1113-1121. https://doi.org/10.3389/fenvs.2014.00053

Blum, A., \& Ebercon, A. (1981). Cell membrane stability as a measure of drought and heat $\begin{array}{llll}\text { tolerance } \quad \text { in } \quad \text { wheat. } & \text { Science, } & \text { 21(1), }\end{array}$ https://doi.org/10.2135/cropsci1981.0011183X002100010013x

Bordallo, P. N., Pereira, M. G., Amaral Junior, A. T., \& Gabriel, A. P. C. (2005). Análise dialélica de genótipos de milho doce e comum para caracteres agronômicos e proteína total. Horticultura Brasileira, 23(1), 123-127. https://doi.org/10.1590/S0102-05362005000100026

Bray, E. A., Bailey-Serres, J., \& Weretilnyk, E. (2000). Responses to abiotic stresses. In: B.B. Buchanan, W. Gruissem, R.L. Jones, (Eds.), Biochemistry \& Molecular Biology of Plants (pp. 1158-1203). Rockville: Amer. Soc. of Plant Phys.

Cakmak, I., \& Horst, W. J. (1991). Effect of aluminum on lipid peroxidation, superoxide dismutase, catalase, and peroxidase activities in root tips of soybean (Glycine max). Physiologia Plantarum, 83(3), 463-468. https://doi.org/10.1111/j.1399-3054.1991.tb00121.x

Costa, W., Zorb, C., Hartunge, W., \& Schubertb, S. (2007). Salt resistance is determined by osmotic adjustment and abscisic acid in newly developed maize hybrids in the first phase of salt stress. Physiologia Plantarum, 131(2), 311-321.

https://doi.org/10.1111/j.1399-3054.2007.00962.x 
Farooq, M., Hussain, M., Wakeel, A., \& Siddique, K. H. M. (2015). Salt stress in maize: effects, resistance mechanisms, and management. A review. Agronomy for Sustainable Development, 35(2), 461-481. https://doi.org/10.1007/s13593-015-0287-0

Ferreira, D. F. (2011). Sisvar: a computer statistical analysis system. Ciência e Agrotecnologia, 35(6), 1039-1042. https://doi.org/10.1590/S1413-70542011000600001

Gaspar, T., Franck, T., Bisbis, B., Kevers, C., Jouve, L., Hausman, J. F., \& Dommes, J. (2002). Concepts in plant stress physiology: application to plant tissue cultures. Plant Growth Regulation, 37(3), 263-285. https://doi.org/10.1023/A:1020835304842

Hajlaoui, H., ElAyeb, N., Garrec, J. P., \& Denden, M. (2010). Differential effects of salt stress on osmotic adjustment and solutes allocation on the basis of root and leaf tissue senescence of two silage maize (Zea mays L.) varieties. Industrial Crops and Products, 31(1), 122-130. https://doi.org/10.1016/j.indcrop.2009.09.007

Hoagland, D. R., \& Arnon, D. L. (1950). The water culture methods for growing plants without soil. Berkeley: Calif. Agric. Exp. Stat. 32p. (Bulletin, 347). https://sayurankitadotcom.files.wordpress.com/2016/04/the-water-culture-method-for-growin g-plants-without-soil.pdf

Hsiao, T. C., \& Xu, L. K. (2000). Sensitivity of growth of roots versus leaves to water stress: biophysical analysis and relation to water transport. Journal of Experimental Botany, 51(350), 1595-1616. https://doi.org/10.1093/jexbot/51.350.1595

Islã, R., \& Aragués, R. (2010). Yield and plant ion concentrations in maize (Zea mays L.) subject to diurnal and nocturnal saline sprinkler irrigations. Field Crops Research, 116(1-2). 175-183. https://doi.org/10.1016/j.fcr.2009.12.008

Kaya, C., Sönmez, O., Aydemir, S., \& Díkílítaş, M. (2013). Mitigation effects of glycine betaine on oxidative stress and some key growth parameters of maize exposed to salt stress. Turkish Journal of Agriculture and Forestry, 37(2), 188-194.

http://dx.doi.org/10.3906/tar-1205-18

Lima, M. G. S., Lopes, N. F., Bacarin, M. A., \& Mendes, C. R. (2004). Efeito do estresse salino sobre a concentração de pigmentos e prolina em folhas de arroz. Bragantia, 63(3), 335-340. https://doi.org/10.1590/S0006-87052004000300003

Luz, J. M. Q., Camilo, J. S., Barbieri, V. H. B., Rangel, R. M., \& Oliveira, R. C. (2014). Produtividade de genótipos de milho doce e milho verde em função de intervalos de colheita. Horticultura Brasileira, 32(2), 163-167. https://doi.org/10.1590/S0102-05362014000200007

Mansour, M. M. F., Salama, K. H. A., Ali, F. Z. M., \& AbouHadid, A. F. (2005). Cell and plant responses to $\mathrm{NaCl}$ Zea mays L. cultivars differing in salt tolerance. General and Applied Plant Physiology, 31(1-2), 29-41. https://www.researchgate.net/publication/258339873

Mendonça, A. V. R., Carneiro, J. G. A., Freitas, T. A. S., \& Barroso, D. G. (2010). Características fisiológicas de mudas de Eucalyptus spp. submetidas a estresse salino. Ciência Florestal, 20(2), 255-267. https://doi.org/10.5902/198050981850

Morales, M. A., Olmos, E., Torrecillas, A., \& Alarcon, J. J. (2001). Differences in water 
relations, leaf ion accumulation and excretion rates between cultivated and wild species of Limonium sp. grown in conditions of saline stress. Flora, 196(5), 345-352. https://doi.org/10.1016/S0367-2530(17)30070-1

Munns, R. (2002). Comparative physiology of salt and water stress. Plant, Cell \& Enviroment, 25(2), 239-250. https://doi.org/10.1046/j.0016-8025.2001.00808.x

Munns, R., \& Tester, M. (2008). Mechanisms of salinity tolerance. The Annual Review of Plant Biology, 59(1), 651-681. https://doi.org/10.1146/annurev.arplant.59.032607.092911

Oliveira Junior, L. F. G., Deliza, R., Bressan-Smith, R., Pereira, M. G., \& Chiquiere, T. B. (2006). Seleção de genótipos de milho mais promissores para o consumo in natura. Ciência e Tecnologia de Alimentos, 26(1), 159-165.

https://doi.org/10.1590/S0101-20612006000100026

Pedrotti, A., Chagas, R. M., Ramos, V. C., Prata, A. P. N., Lucas, A. A. T., \& Santos, P. B. (2015). Causas e consequências do processo de salinização dos solos. Revista Eletrônica em Gestão, Educação e Tecnologia Ambiental, 19(2), 1308-1324. https://doi.org105902/2236117016544

Rady, M. M., \& Hemida, K. A. (2016). Sequenced application of ascorbate-proline-glutathione improves salt tolerance in maize seedlings. Ecotoxicology and Environmental Safety, 133, 252-259. https://doi.org/10.1016/j.ecoenv.2016.07.028

Ragagnin, R. C. G., Alburqueque, C. C., Oliveira, F. F. M., Santos, R. G., Gurgel, E. P., Diniz, J. C., ... \& Viana, F. A. (2014). Effect of salt stress on the growth of Lippiagracilis Schauer and on the quality of its essential oil. Acta Botanica Brasilica, 28(3), 346-351. https://doi.org/10.1590/0102-33062014abb3369

Rahimi, R., Mohammakhani, A., Roohi, V., \& Armand, N. (2012). Effects of salt stress and silicon nutrition on cholorophyll content, yield and yield components in fennel (Foeniculum vulgare Mill.). International Journal of Agriculture and Crop Sciences, 4(21), 1591-1595.

Richter, J. A., Erban, A., Kopka, J., \& Zorb, C. (2015). Metabolic contribution to salt stress in two maize hybrids with contrasting resistance. Plant Science, 233, 107-115.

https://doi.org/10.1016/j.plantsci.2015.01.006

Santos, R. G., Albuquerque, C. C., Paiva, D. C. C., Oliveira, F. F. M., Ragagnin, C. G., \& Cipriano, A. (2016). Performance on tolerance of the AL Bandeirantes maize cultivar under salt stress. Magistra, 28(3-4), 352-359.

Shtereva, L. A., Vassilevska-Ivanova, R. D., \& Karceva, T. V. (2015). Effect of salt stress on some sweet corn (Zea mays L. var. saccharata) genotypes. Archives of Biological Sciences, 67(3), 993-1000. https://doi.org/10.2298/ABS150121062S

Silva, E. N., Ribeiro, R. V., Ferreira-Silva, S. L., Viégas, R. A., \& Silveira, J. A. G. (2011). Salt stress induced damages on the photosynthesis of physic nut young plants. Scientia Agricola, 68(1), 62-68. https://doi.org/10.1590/S0103-90162011000100010

Silva, E. N., Silveira, J. A. G., Rodrigues, C. R. F., Lima, C. S., \& Viégas, R. A. (2009). Contribution of organic and inorganic solutes to osmotic adjustment of physic nut under 
salinity. Pesquisa Agropecuária Brasileira, 44(5), 437-445.

https://doi.org/10.1590/S0100-204X2009000500002

Silveira, J. A. G., Melo, A. R. B., Viégas, R. A., \& Oliveira, J. T. A. (2001). Salt-induced effects on the nitrogen assimilation related to growth in cowpea plants. Environmental and Experimenal Botany, 46(2), 171-179. https://doi.org/10.1016/S0098-8472(01)00095-8

Silveira, J. A. G., Silva, S. L. F., Silva, E. M., \& Viégas, R. A. (2010). Mecanismos biomoleculares envolvidos com a resistência ao estresse salino em plantas. In: H.R. Gheyi, N.S. Dias, C.F. Lacerda (Eds.), Manejo da salinidade na agricultura: estudos básicos e aplicados (pp. 167-185). Fortaleza: Instituto Nacional de Ciência e Tecnologia em Salinidade.

Soares Filho, W., Gheyi, H. R., Brito, M. E. B., Fernande, P. D., \& Miranda, R. S. (2016). Melhoramento genético vegetal e seleção de cultivares tolerantes à salinidade. In: H.R. Gheyi, N.S. Dias, C.F. Lacerda, E. Gomes Filho. Manejo da salinidade na agricultura: estudos básicos e aplicados (pp. 259-274). Fortaleza: Instituto Nacional de Ciência e Tecnologia em Salinidade.

Sousa, G. G., Lacerda, C. F., Cavalcante, L. F., Guimarães, F. V. A., Bezerra, M. E. J., \& Silva, G. L. (2010). Nutrição mineral e extração de nutrientes de planta de milho irrigada com água salina. Revista Brasileira de Engenharia Agrícola e Ambiental, 14(11), 1143-1151. https://doi.org/10.1590/S1415-43662010001100003

Souza, M. W. L., Cunha, R. C., Costa, P. A. A., Moura, I. N. B. M., Bezerra, F. M. S., Lima, L.A., ... Oliveira, F. A. (2014). Desenvolvimento inicial de milho doce e milho pipoca sob estresse salino. Agropecuária Científica no Semi-Árido, 10(3), 65-72.

http://150.165.111.246/ojs-patos/index.php/ACSA

Taiz, L., \& Zeiger, E. (2009). Fisiologia vegetal. (4. ed.). Porto Alegre: Artmed. 819p.

Tracy, W. F. (2001). Sweet corn. In: A.R. Hallauer (Eds), Specialty corn (pp. 155-198). Boca Raton: CRC Press. https://doi.org/10.1201/9781420038569.ch6

Willadino, L., \& Camara, T. R. (2010). Tolerância das plantas à salinidade: aspectos fisiológicos e bioquímicos. Enciclopédia Biosfera - Centro Científico Conhecer, 6(11), 1-23. http://www.conhecer.org.br/enciclop/2010c/tolerancia\%20das\%20plantas.pdf

Zhu, J. T., Li, X. Y., Zhang, X. M., Zeng, F. J., Lin, L. S., Yang, S. G., .. Wang, H. (2010). Ecophysiological adaptation of Calligonum roborovskii to decreasing soil water content along an altitudinal gradient in the Kunlun Mountains, Central Asia. Russian Journal of Plant Physiology, 57(6), 826-832. https://doi.org/10.1134/S1021443710060117

\section{Copyright Disclaimer}

Copyright for this article is retained by the author(s), with first publication rights granted to the journal.

This is an open-access article distributed under the terms and conditions of the Creative Commons Attribution license (http://creativecommons.org/licenses/by/4.0/). 